This article is licensed under the Creative Commons Attribution-NonCommercial 4.0 International License (CC BY-NC) (http://www.karger.com/Services/OpenAccessLicense). Usage and distribution for commercial purposes requires written permission.

\title{
Reocclusion after Self-Expandable Metallic Stent Placement for Relieving Malignant Colorectal Obstruction as a Palliative Treatment
}

\author{
Toshikatsu Nitta $^{a} \quad K^{2}$ sensuke Fujii ${ }^{a}$ Yoshimasa Hirata ${ }^{b}$ Tomo Tominaga ${ }^{a}$ \\ Yoshihiro Inoue $^{a}$ Hiroshi Kawasaki $^{\mathrm{a}}$ Ken Kawakami $^{\mathrm{b}}$ Takashi Ishibashi $^{\mathrm{a}}$ \\ a Division of Surgery, Gastroenterological Center, Medico Shunjyu Shiroyama Hospital, \\ Habikino City, Japan; ${ }^{b}$ Division of Internal Medicine, Gastroenterological Center, Medico \\ Shunjyu Shiroyama Hospital, Habikino City, Japan
}

\section{Keywords}

Reocclusion · Self-expandable metallic stent placement - Malignant colorectal obstruction ·

Palliative treatment

\section{Abstract}

Self-expandable metallic stent (SEMS) placement has been practiced in several hospitals in Japan, including ours, since January 2012. Here, we report the case of an 82-year-old Japanese man who presented to the hospital with a 1-week history of right hypochondrial pain. Computed tomography (CT) findings indicated colorectal cancer. The laboratory findings on admission indicated severe anemia (red blood cell count, $426 \times 104 / \mu \mathrm{L}$; hemoglobin, 7.9 $\mathrm{g} / \mathrm{dL}$ ). We performed SEMS placement because the patient refused to undergo surgery. He 


\section{Case Reports in \\ Gastroenterology}

Case Rep Gastroenterol 2016;10:733-742

DOI: $10.1159 / 000452200$

(C) 2016 The Author(s). Published by S. Karger AG, Base www.karger.com/crg

Nitta et al.: Reocclusion after Self-Expandable Metallic Stent Placement for Relieving

Malignant Colorectal Obstruction as a Palliative Treatment

did not attend any of the scheduled follow-up visits after SEMS placement. However, a year and a half after the SEMS placement, the patient attended the hospital because of difficulty in passing stool. A plain abdominal CT scan showed bowel reobstruction due to the ascending colon cancer after SEMS placement. We performed an emergency operation, ascending colostomy, on the same day. Colorectal stent placement may be a good treatment option for patients who refuse to undergo conventional therapeutic treatments or in those with unresectable colorectal cancer. Patients should be carefully followed up every few months after SEMS placement because of the risk of reocclusion.

(C) 2016 The Author(s)

Published by S. Karger AG, Basel

\section{Introduction}

Since self-expandable metallic stent (SEMS) placement started being covered by insurance in Japan in January 2012, SEMS placement has been practiced in several hospitals in Japan, including ours. The insertion of SEMS was performed under endoscopic and fluoroscopic guidance by endoscopists and surgeons. Wallflex colonic stents (Boston Scientific, Natick, MA, USA) were used in the majority of the patients in our hospital.

In 2014, the European Society of Gastrointestinal Endoscopy (ESGE) [1] expressed some concern regarding the efficacy of SEMS in cases of colorectal cancer ileus. While colostomy is the definitive treatment for malignant colonic obstruction, SEMS placement is strongly recommended as the preferred palliative treatment for malignant colonic obstruction [1]. The use of SEMS placement as a palliative treatment for malignant colonic obstruction is becoming popular as an alternative to colonic stoma. SEMS placement can decrease the occurrence of complications compared with colostomy. However, adverse events related to SEMS placement have been reported recently.

Here, we report a case of reocclusion after SEMS placement. Accordingly, we investigated the efficacy of SEMS placement as a palliative treatment among patients treated in our hospital.

\section{Case Report}

An 82-year-old Japanese man was suffering from right hypochondrial pain for 1 week and visited our hospital. The laboratory findings on admission indicated severe anemia (red blood cell count, $426 \times 10^{4} / \mu \mathrm{L}$; hemoglobin, $7.9 \mathrm{~g} / \mathrm{dL}$ ). However, other laboratory findings were within normal limits (Table 1). An abdominal computed tomography (CT) scan demonstrated wall thickening in the ascending colon with some swollen regional lymph nodes, indicating a diagnosis of colon cancer. The patient was admitted to the Gastroenterological Center of our hospital.

We planned a right hemicolectomy, but the patient refused to undergo surgery. He agreed to undergo colonoscopy, which showed a type 2 tumor in the ascending colon (Fig. 1). The stenosing lesion was stented by a combined endoscopic and fluoroscopic approach. Using an endoscope, a guide wire was introduced across the stenosis and beyond the obstruction. The SEMS was inserted through the endoscope over the guide wire and deployed 


\section{Case Reports in \\ Gastroenterology}

Case Rep Gastroenterol 2016;10:733-742

(c) 2016 The Author(s). Published by S. Karger AG, Basel www.karger.com/crg

Nitta et al: Reocclusion after Self-Expandable Metallic Stent Placement for Relieving

Malignant Colorectal Obstruction as a Palliative Treatment

in place. We used a $22 \times 60$-mm stent (Wallflex colonic stent; Boston Scientific). Fig. 2 shows a radiography image taken after the stent had been placed in the ascending colon. The patient was discharged 3 days after the procedure. He did not attend any of the scheduled follow-up visits after SEMS placement.

A year and a half after the SEMS placement, the patient attended the hospital because of difficulty in passing stool and reocclusion. A mass palpated in the right subcostal region was identified as the colon cancer. A plain abdominal CT scan showed bowel reobstruction due to the ascending colon cancer after SEMS placement. Fig. 3 shows significant dilatation of the ascending colon with the SEMS in the abdominal CT scan. A coronal section of the abdominal CT scan revealed the presence of a mass in the ascending colon and cecum (Fig. 4). We performed an emergency operation, ascending colostomy, on the same day. The patient demonstrated a good postoperative course and was discharged from our hospital in remission 16 days after the surgery. He has been followed up every few months for over 3 years and has not required any adjuvant chemotherapy.

\section{Discussion}

Dohomoto first described SEMS placement in 1991 [2, 3]. Recently, there have been reports of colonic stents to relieve colonic obstruction, with the stents used as a bridge to surgery $[4,5]$. However, since the first report in 1991, SEMS have been used for palliative treatment of obstructed colorectal cancer to avoid surgery.

Colorectal cancer is among the most common malignant diseases, and colorectal obstruction has been reported in 7-29\% of patients with colorectal cancer [6]. Patients presenting with acute colorectal obstruction due to cancer have both a higher operative mortality rate and a poor overall survival than nonobstructive cases [7, 8]. Surgeons have been performing initial decompressive operation with a stoma to relieve the symptoms of the stenosis caused by cancer. Colorectal obstruction has been considered to require emergency surgery to relieve the obstruction as soon as possible. However, surgical procedures such as resection and primary anastomosis, Hartmann's procedure, subtotal or total colectomy, diverting stoma formation, and even only stoma formation without colectomy are invasive techniques. Stoma formation may help improve the patient's quality of life, especially when used as palliative treatment. Evidently, in patients with unresectable colorectal cancer, the aim is to improve their quality of life. For this reason, a minimally invasive decompressive procedure such as SEMS placement is a good option for palliative treatment instead of surgery.

There are some risks with SEMS placement. According to Tilney et al. [9], potential complications after insertion of a colonic stent include perforation, bleeding, stent migration, reobstruction, and pain [10]. In the ESGE Clinical Guideline [1], SEMS placement is strongly recommend as the preferred treatment for palliation of malignant colonic obstruction based on the evidence. Patients who underwent SEMS placement had a shorter hospitalization (10 vs. 19 days) and a lower intensive care unit admission rate (0.8 vs. $18.0 \%)$ than those who underwent surgery $[11,12]$. However, while short-term complications occurred more often in the surgery group, late complications were more frequent in the SEMS group [12]. Stent- 
related complications mainly included reobstruction (18\%), colonic perforation (10\%), and stent migration (9\%) [12].

Regarding reobstruction, the median stent patency in the palliative setting ranges widely between 55 and 343 days $[13,14]$. A previous study reported a median stent patency of 106 days (range, 68-288 days) in the SEMS group [15]. Tumor ingrowth and overgrowth causes stent reobstruction and usually occurs during the long-term course of stent therapy [1]. Reobstruction could be managed endoscopically. Stent replacement and stent reopening by a stent-in-stent have been reported as the preferred methods to manage reobstruction, with satisfactory results (clinical success, $75-86 \%$ ) $[1,16,17]$.

Colorectal stent placement as palliative care is effective in terms of averting surgery. However, further emergency intervention or surgical treatment may be necessary in some cases. We should recommend patients to undergo radical operation if they are shown to be good candidates to overcome colon cancer. In the present case, although the patient was a good candidate for surgery, he did not provide informed consent, and thus we were unable to perform the surgery. We should have insisted that the patient visit our hospital for followup every few months after the procedure. The patient presented reobstruction after SEMS placement, and the surgery was eventually performed after the patient had provided informed consent.

In conclusion, colorectal stent placement may be a good treatment option for patients who refuse to receive conventional therapeutic strategies or in those with unresectable colorectal cancer. However, patients should be carefully followed up every few months after SEMS placement because of the risk of reocclusion. It is necessary for endoscopists and surgeons to work together and develop management strategies that support reintervention and surgery.

\section{Statement of Ethics}

The authors have no ethical conflicts to disclose.

\section{Disclosure Statement}

None of the authors has any conflict of interest to declare.

\section{References}

\footnotetext{
$\checkmark 1$ van Hooft JE, van Halsema EE, Vanbiervliet G, et al: Self-expandable metal stents for obstructing colonic and extracolonic cancer: European Society of Gastrointestinal Endoscopy (ESGE) Clinical Guideline. Endoscopy 2014;46:990-1053.

2 Dohomoto M: New method - endoscopic implantation of rectal stent in palliative treatment of malignant stenosis. Endosc Dig 1991;3:1507-1512.

-3 Dohomoto M, Hunerbein M, Schlag PM: Palliative endoscopic therapy of rectal carcinoma. Eur J Cancer 1996;32A:25-29.
} 
4 Martinez-Santos C, Lobato RF, Fradejas JM, et al: Self-expandable stent before elective surgery vs. emergency surgery for the treatment of malignant colorectal obstructions: comparison of primary anastomosis and morbidity rates. Dis Colon Rectum 2002;45:401-406. expandable metallic stent insertion for obstructive colorectal cancer: comparison with emergency operation. Dis Colon Rectum 2003;46(10 suppl):S44-S49.

Deans GT, Krukowski ZH, Irwin ST: Malignant obstructions of the left colon. Br J Surg 1994;81:12701276.

Ohman U: Prognosis in patients with obstructing colorectal carcinoma. Am J Surg 1982;143:742-747. Serpell JW, McDermott FT, Kartrivessis H, et al: Obstructing carcinoma of the colon. Br J Surg 1989;76:965-969.

-9 Tilney HS, Lovegrove RE, Purkayastha S, et al: Comparison of colonic stenting and open surgery malignant large bowel obstruction. Surg Endosc 2007;21:225-233.

10 Baron TH, Kozarek RA: Endoscopic stenting of colonic tumours. Best Pract Res Clin Gastroenterol 2004;18:209-229.

11 Liang TW, Sun Y, Wei YC, et al: Palliative treatment of malignant colorectal obstruction caused by advanced malignancy: a self-expanding metallic stent or surgery? A system review and meta-analysis. Surg Today 2014;44:22-33.

$\$ 12$ Zhao XD, Cai BB, Cao RS, et al: Palliative treatment for incurable malignant colorectal obstructions: a meta-analysis. World J Gastroenterol 2013;19:5565-5574.

13 Cheung DY, Kim JY, Hong SP, et al: Outcome and safety of palliative self-expandable metallic stents for malignant colon obstruction: a Korean multicenter randomized prospective study. Surg Endosc 2012;26:3106-3113.

14 Park JK, Lee MS, Ko BM, et al: Outcome of palliative self-expanding metal stent placement in malignant colorectal obstruction according to stent type and manufacturer. Surg Endosc 2011;25:1293-1299.

15 Watt AM, Faragher IG, Griffin TT, et al: Self-expanding metallic stents for relieving malignant colorectal obstruction: a systematic review. Ann Surg 2007;246:24-30.

-16 Yoon JY, Park SJ, Hong SP, et al: Outcomes of secondary self-expandable metal stents versus surgery after delayed initial palliative stent failure in malignant colorectal obstruction. Digestion 2013;88:4655.

17 Yoon JY, Jung YS, Hong SP, et al: Outcomes of secondary stent-in-stent self-expandable metal stent insertion for malignant colorectal obstructions. Gastrointest Endosc 2011;74:625-633. 
Nitta et al.: Reocclusion after Self-Expandable Metallic Stent Placement for Relieving Malignant Colorectal Obstruction as a Palliative Treatment

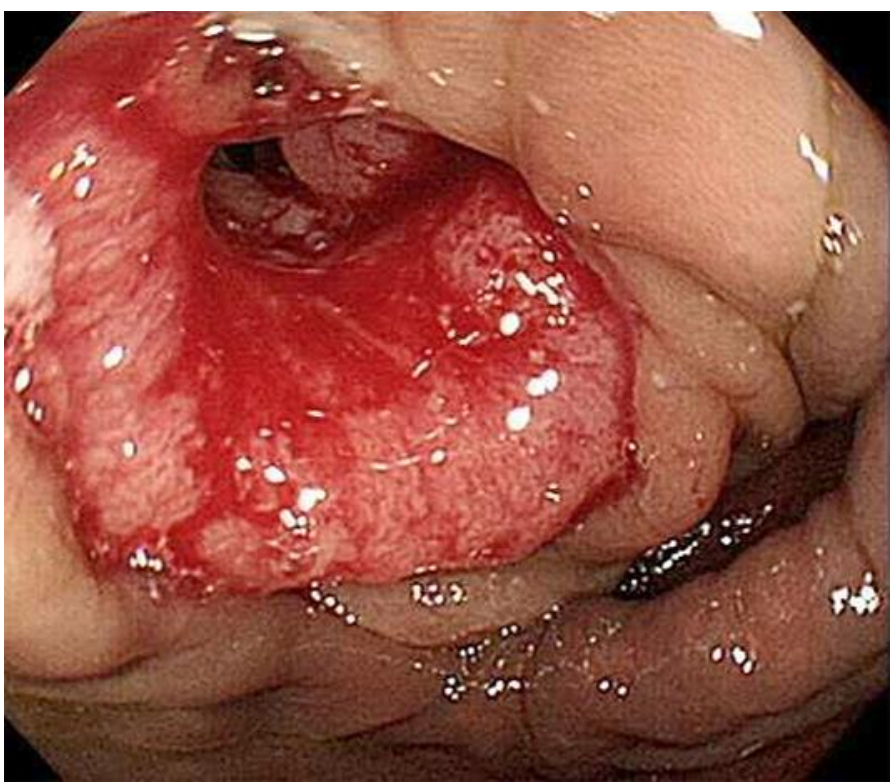

Fig. 1. Colonoscopy findings. Colonoscopy examination showed a type 2 tumor in the ascending colon. 


\section{Case Reports in \\ Gastroenterology}

Nitta et al:: Reocclusion after Self-Expandable Metallic Stent Placement for Relieving

Malignant Colorectal Obstruction as a Palliative Treatment

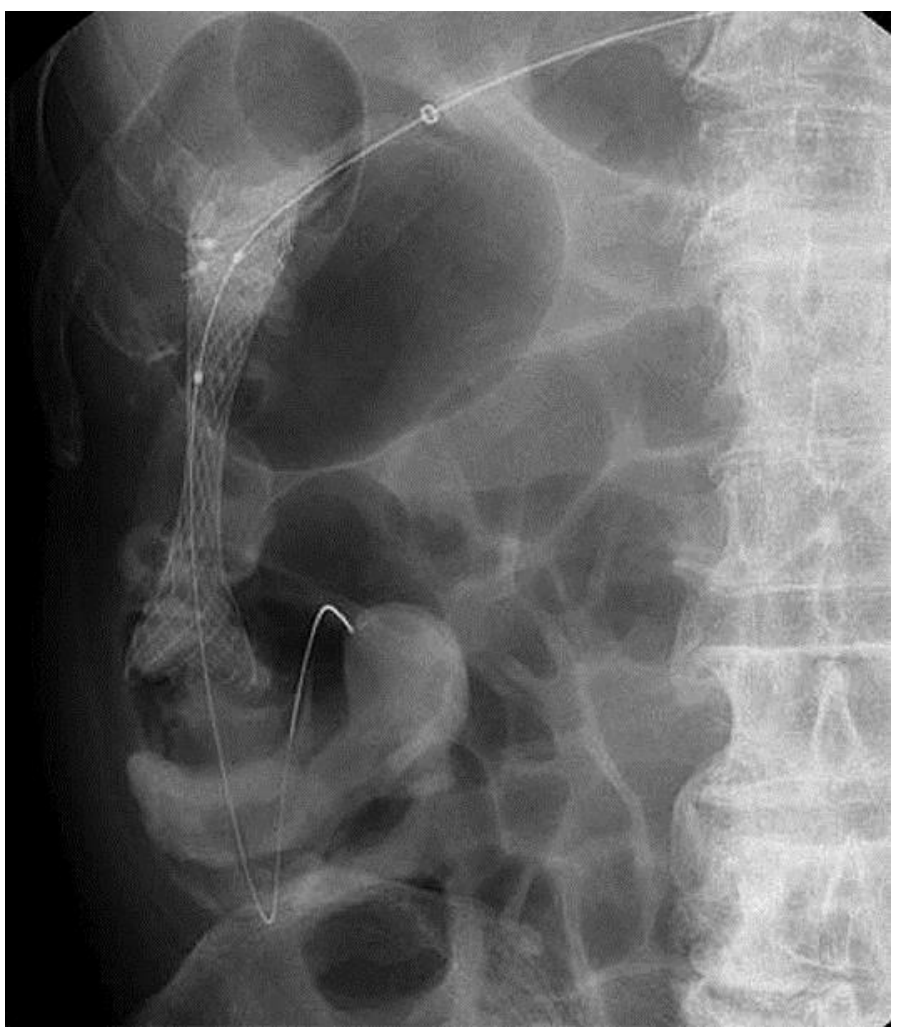

Fig. 2. Preoperative radiography findings. Radiograph image of the patient after the stent was placed in the ascending colon. The stenosing lesion was stented by a combined endoscopic and fluoroscopic approach. 


\begin{tabular}{ll|l} 
Case Reports in & \multicolumn{2}{l}{ Case Rep Gastroenterol 2016;10:733-742 } \\
\cline { 2 - 3 } Gastroenterology $10.1159 / 000452200$ & $\begin{array}{l}\text { @ 2016 The Author(s). Published by S. Karger AG, Basel } \\
\text { www.karger.com/crg }\end{array}$ \\
\cline { 2 - 3 } & &
\end{tabular}

Nitta et al.: Reocclusion after Self-Expandable Metallic Stent Placement for Relieving Malignant Colorectal Obstruction as a Palliative Treatment

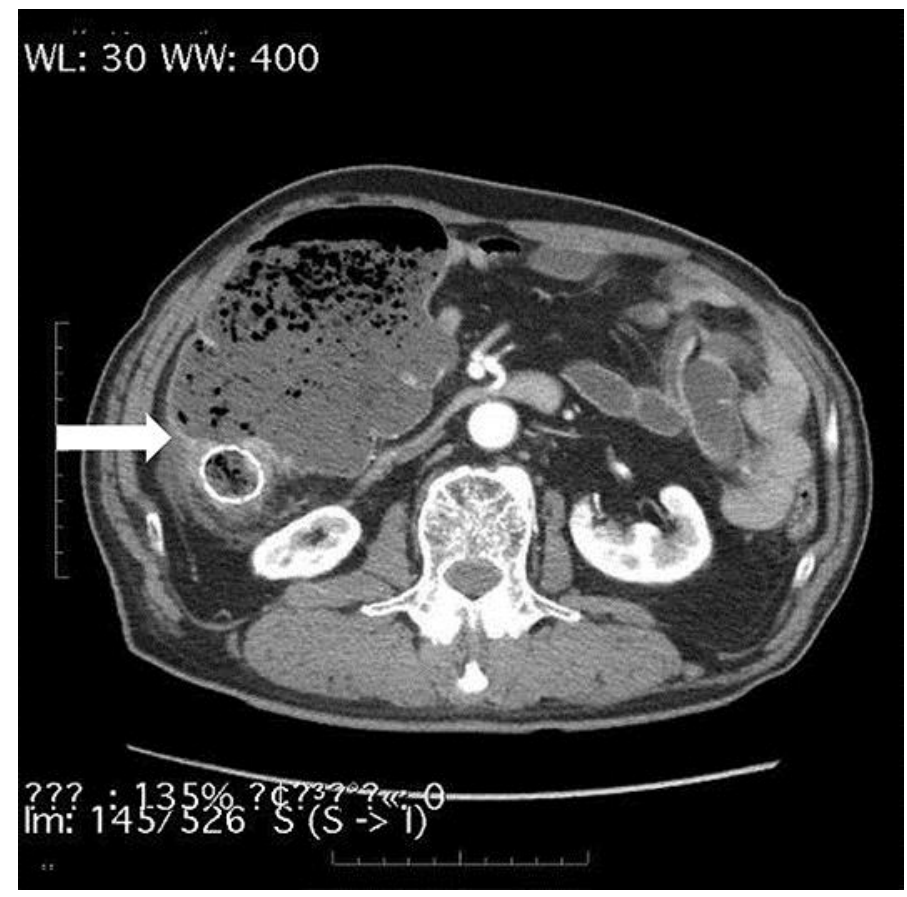

Fig. 3. Preoperative abdominal computed tomography (CT) findings. A plain abdominal CT scan shows bowel reobstruction due to the ascending colon cancer after self-expandable metallic stent placement (arrow). 


\begin{tabular}{ll|l} 
Case Reports in & \multicolumn{2}{l}{ Case Rep Gastroenterol 2016;10:733-742 } \\
\cline { 2 - 3 } Gastroenterology $10.1159 / 000452200$ & $\begin{array}{l}\text { @ 2016 The Author(s). Published by S. Karger AG, Basel } \\
\text { www.karger.com/crg }\end{array}$ \\
\cline { 2 - 3 } & &
\end{tabular}

Nitta et al.: Reocclusion after Self-Expandable Metallic Stent Placement for Relieving Malignant Colorectal Obstruction as a Palliative Treatment

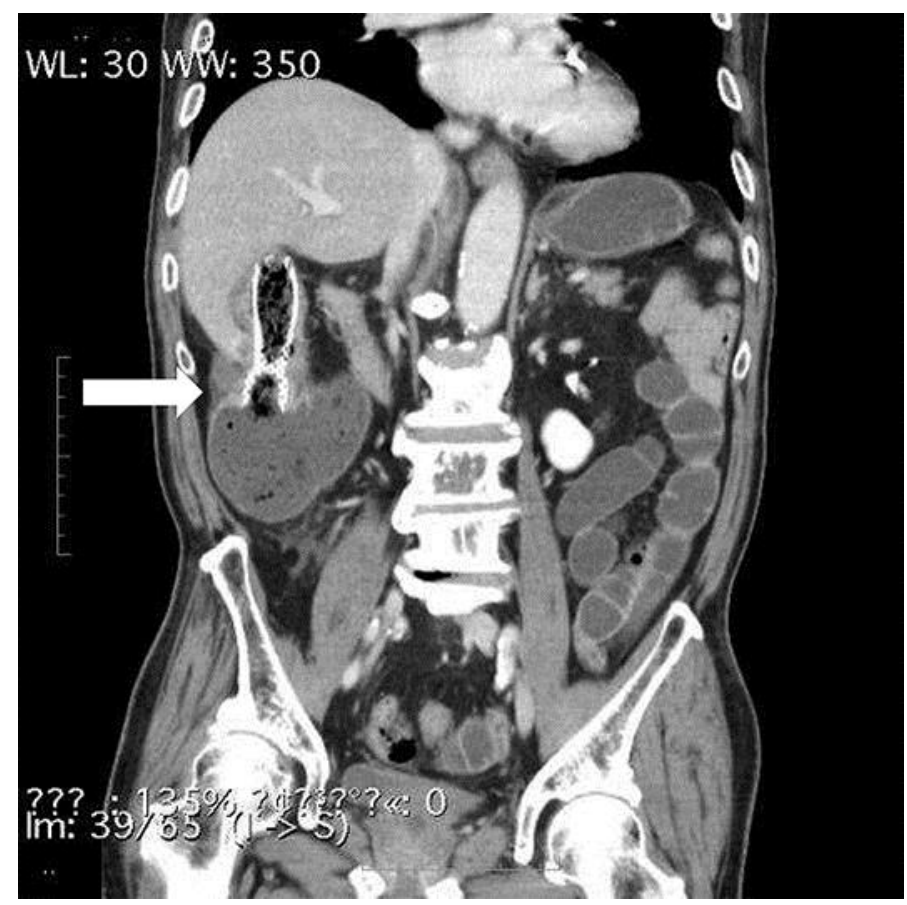

Fig. 4. Preoperative abdominal computed tomography (CT) findings. An abdominal CT scan (coronal section) revealed the presence of a mass in the ascending colon and cecum (arrow). 
Table 1. Laboratory findings

\begin{tabular}{|c|c|c|}
\hline Variable & Range & On admission \\
\hline \multicolumn{3}{|l|}{ Peripheral blood } \\
\hline $\mathrm{WBC}, / \mu \mathrm{L}$ & $3,900-9,800$ & 6,700 \\
\hline $\mathrm{RBC}, / \mu \mathrm{L}$ & $430-570$ & $361 \times 10^{4}$ \\
\hline Hemoglobin, g/dL & $13.5-17.6$ & 7.9 \\
\hline Hematocrit, \% & $40.0-52.0$ & 27.4 \\
\hline Platelet count, $/ \mu \mathrm{L}$ & $12.0-34.0$ & $34.3 \times 10^{4}$ \\
\hline \multicolumn{3}{|l|}{ Tumor markers } \\
\hline CEA, ng/mL & $0-5.0$ & 1.3 \\
\hline CA19-9, U/mL & $0-37$ & 5 \\
\hline \multicolumn{3}{|l|}{ Blood chemistry } \\
\hline Total protein, g/dL & $6.5-8.3$ & 6.6 \\
\hline Albumin, g/dL & $3.8-5.2$ & 4.2 \\
\hline Total bilirubin, mg/dL & $0.2-1.2$ & 0.4 \\
\hline AST, IU/L & $10-40$ & 11 \\
\hline ALT, IU/L & $5-45$ & 8 \\
\hline ALP, IU/L & $110-340$ & 297 \\
\hline$\gamma$-GTP, U/L & $12-87$ & 22 \\
\hline LDH, IU/L & $107-230$ & 139 \\
\hline BUN, mg/dL & $8.0-20.0$ & 17.0 \\
\hline Creatinine, mg/dL & $0.61-1.04$ & 0.81 \\
\hline Sodium, mEq/L & $135-147$ & 143 \\
\hline Potassium, mEq/L & $3.3-5.0$ & 3.6 \\
\hline Chloride, mEq/L & $98-108$ & 109 \\
\hline CPK, IU/L & $45-190$ & 84 \\
\hline \multicolumn{3}{|l|}{ Serological tests } \\
\hline $\mathrm{CRP}, \mathrm{mg} / \mathrm{dL}$ & $0-0.30$ & 0.05 \\
\hline HBsAg & & $(-)$ \\
\hline $\mathrm{HBsAb}$ & & $(-)$ \\
\hline HCVAb & & $(-)$ \\
\hline \multicolumn{3}{|l|}{ Coagulation } \\
\hline Prothrombin time, s & $10.5-13.5$ & 12.7 \\
\hline Prothrombin time, $\%$ & $70-130$ & 79.1 \\
\hline aPTT, s & $25-40$ & 37.9 \\
\hline
\end{tabular}

ALP, alkaline phosphatase; ALT, alanine aminotransferase; aPTT, activated partial thromboplastin time; AST, aspartate aminotransferase; BUN, blood urea nitrogen; CEA, carcinoembryonic antigen; CPK, creatine phosphokinase; CRP, C-reactive protein; $\gamma$-GTP, gammaglutamyl transferase; HBsAb, hepatitis B surface antibody; HBsAg, hepatitis B surface antigen; HCVAb, hepatitis C virus antibody; $\mathrm{LDH}$, lactate dehydrogenase; RBC, red blood cell count; WBC, white blood cell count. 